\title{
A SYSTEMATIC REVIEW OF ALUMINIUM PHOSPHIDE POISONING
}

\author{
Omid MEHRPOUR ${ }^{1,2}$, Mostafa JAFARZADEH $^{3}$, and Mohammad ABDOLLAHI ${ }^{4}$
}

Department of Clinical Toxicology ${ }^{l}$, Medical Toxicology and Drug Abuse Research Center ${ }^{2}$, Birjand University of Medical Sciences (BUMS), Birjand, Department of Forensic Medicine and Toxicology, Faculty of Medicine 3 , Faculty of Pharmacy, and Pharmaceutical Sciences Research Center ${ }^{4}$, Tehran University of Medical Sciences, Tehran, Iran

Received in December 2011

CrossChecked in December 2011

Accepted in February 2012

\begin{abstract}
Every year, about 300,000 people die because of pesticide poisoning worldwide. The most common pesticide agents are organophosphates and phosphides, aluminium phosphide (AIP) in particular. AlP is known as a suicide poison that can easily be bought and has no effective antidote. Its toxicity results from the release of phosphine gas as the tablet gets into contact with moisture. Phosphine gas primarily affects the heart, lungs, gastrointestinal tract, and kidneys. Poisoning signs and symptoms include nausea, vomiting, restlessness, abdominal pain, palpitation, refractory shock, cardiac arrhythmias, pulmonary oedema, dyspnoea, cyanosis, and sensory alterations. Diagnosis is based on clinical suspicion, positive silver nitrate paper test to phosphine, and gastric aspirate and viscera biochemistry. Treatment includes early gastric lavage with potassium permanganate or a combination with coconut oil and sodium bicarbonate, administration of charcoal, and palliative care. Specific therapy includes intravenous magnesium sulphate and oral coconut oil. Moreover, acidosis can be treated with early intravenous administration of sodium bicarbonate, cardiogenic shock with fluid, vasopresor, and refractory cardiogenic shock with intra-aortic baloon pump or digoxin. Trimetazidine may also have a useful role in the treatment, because it can stop ventricular ectopic beats and bigeminy and preserve oxidative metabolism. This article reviews the epidemiological, toxicological, and clinical/pathological aspects of AlP poisoning and its management.
\end{abstract}

KEY WORDS: human poisoning, mechanism of toxicity, phosphine, phosphides, pesticides

Aluminium phosphide (AlP) is a well known, highly effective outdoor and indoor insecticide and rodenticide. It is readily available in Asian markets such as India. Although its use has been banned in Iran, it is still used to protect rice (hence the local name "rice tablet") and stored grains from rodents and other household pests.

Moisture in the air mixes with phosphide grains and sets off phosphine (hydrogen phosphide, phosphorus trihydride, $\mathrm{PH}_{3}$ ), which is the active form of the pesticide. Tablets, pellets, or compressed discs contain phosphide and other substances such as ammonium carbonate. If it comes into contact with an acid, phosphine is released even more vigorously. Two kinds of acute poisoning have been reported: indirect inhalation of phosphine released during approved use or direct ingestion of metal phosphides $(1,2)$.

In an autopsy study of unnatural deaths in Northwest India (1), AlP was found to be the most common suicidal poison, causing $68.4 \%$ of total deaths due to poisoning between 1992 and 2002. This epidemic of suicidal AlP poisoning has also been confirmed by Gupta and Ahlawat (2). Between 1977 and 1987, barbiturates (33.3\%), organophosphates (23.8\%), and copper sulphate $(14.3 \%)$ were the most common causes of death by poisoning and between 1987 and 
1997 they were replaced by organophosphates (45\%) and AlP (26.5 \%). Since 1992, AlP has taken over the lead $(80 \%)$. The incidence of suicidal deaths increased from $10.9 \%$ in 1987 to 1992 to $15.7 \%$ between 1997 and 2002, with a peak incidence of $18.2 \%$ in 1992 to 1997, when AlP became available on the free market. Of all fatal poisonings, suicidal and accidental between 1987 and 1997, AlP accounted for $26.5 \%$. The rate of AlP poisonings in Iran is also high; of 471 cases reported between 2000 and 2007, 146 (31\%) were fatal (3), which is even more serious considering that AlP has been banned for marketing in Iran. In the European countries such as UK, however, AlP is available in the form of tablets, but supply is restricted under the 1998 Pesticides Act to qualified users (4). In the European countries suicides by AlP ingestion are rare and have been reported in Denmark (5), Germany (6), France (7), and the UK (4).

AlP as a solid fumigant may be synthesised as dark gray or dark yellow crystals and can take the form of tablets, pellets, granules, or dust. It is marketed as dark grey $3 \mathrm{~g}$ tablets consisting of AlP $(56 \%)$ and carbamate (44\%), under the brand names such as Celphos, Alphos, Quickphos, Phosfume, Phostoxin, Talunex, Degesch, Synfume, Chemfume, Phostek, and Delicia (8). Phosphine gas has a foul odour resembling decaying fish or garlic because of substituted phosphines and diphosphines.

Ready availability of this fumigant insecticide in Asian countries makes it an important public health concern, especially because no specific treatment or antidote is available. The survival rate is low, but updating knowledge of health professionals and general public may help reduce the risk of poisoning (9).

\section{RESEARCH}

We looked up the terms aluminium, aluminium phosphide, and phosphine in bibliographical databases such as the TUMS digital library, Pubmed, Scopus, and Google Scholar. This review includes relevant articles published between 1990 and 2011.

\section{Epidemiology}

Every year, about 300,000 deaths due to pesticide poisoning are reported worldwide (10). Most reports of acute pesticide poisoning are based on hospital admission records and reflect only a fraction of the real incidence. Most reports of AlP poisoning refer to the young adult population from rural Asian areas (4). In Asia, about 25 million agricultural workers report an episode of poisoning every year (11). In a study conducted in Tehran, Shadnia et al. (3) found that of 77,958 poisonings, 471 people were poisoned with AlP , of whom 146 (31\%) died. This makes AlP a major concern in the Iranian population $(3,12)$.

Of 188 cases of phosphine poisoning reported in Germany between 1983 and 2003, $28 \%$ were intentional, mostly by ingestion, which ended in two fatalities, whereas $65 \%$ were accidental, mostly by inhalation, due to inappropriate self-protection from the released gas, which resulted in only transient gastrointestinal (GI) and respiratory symptoms (13). In the UK, the majority of 93 AlP poisonings reported to the National Poisons Information Service between 1997 and 2003 were accidental and concerned limited exposure to phosphine gas in agricultural locations (4). Only one fatal outcome was reported in this case series.

\section{Mechanism of action}

The exact mechanism of action of AlP is still unknown. However some initial studies on different animals showed that phosphine mainly binds cytochrome oxidase and changes the valences of the haem component of haemoglobin (14). It also induces oxidative stress and boosts extra-mitochondrial release of free oxygen radicals (15) that results in lipid peroxidation and protein denaturation of the cell membrane $(16,17)$ in various organs. Abdollahi et al. (18) believe that oxidative stress is one of the main mechanisms of action of AlP toxicity that is somehow similar to that of organophosphate (OP) compounds. Furthermore, AlP reduces glutathione, which is one of the main antioxidant defences. In fact, AlP and OP alike cause a toxic stress that is accompanied by changes in glucose metabolism $(19,20)$. Al-Azzawi et al. (21) showed that in vitro exposure to phosphine leads to reduction of human serum cholinesterase activity, depending on the duration and phosphine concentration. On the other hand, some studies found no change in erythrocyte cholinesterase activity in accidental phosphine inhalation cases (22).

Figure 1 shows a plausible mechanism of AlP toxicity.

\section{Toxicokinetics}

Judging by the rapid systemic toxicity, phosphine is quickly absorbed after oral ingestion. Phosphine is 


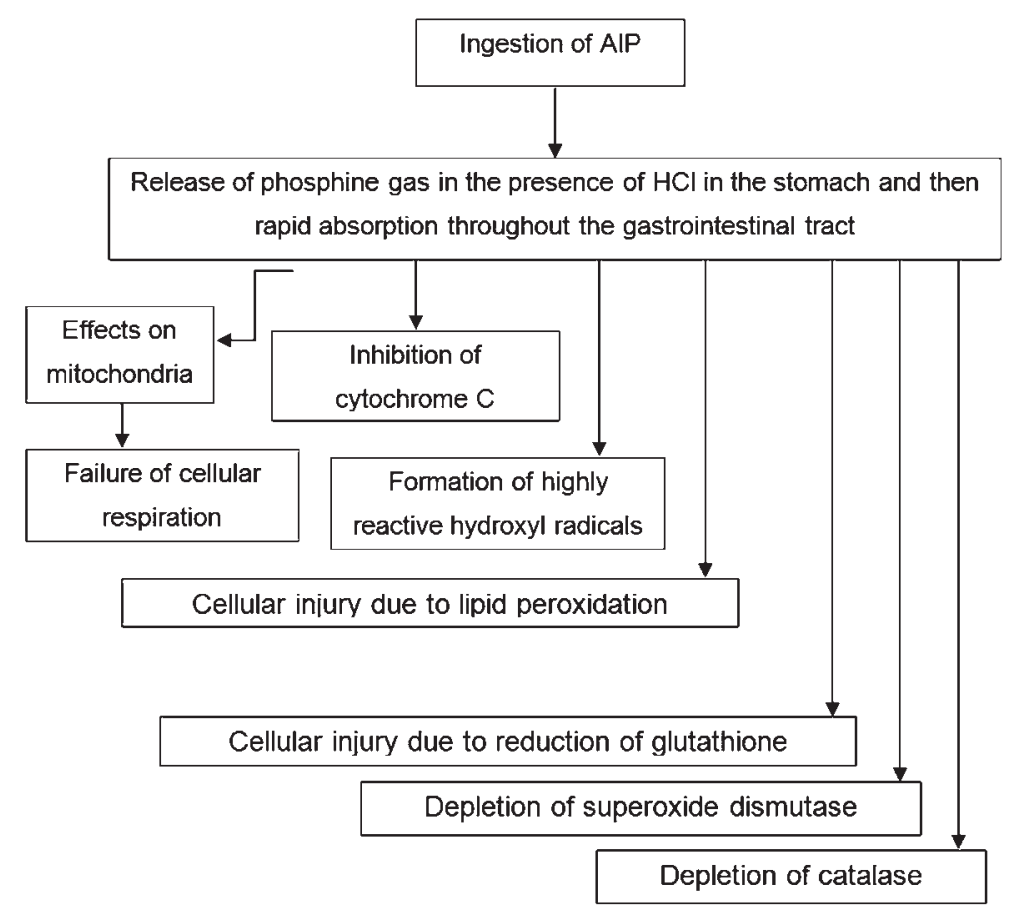

Figure 1 The mechanisms of AlP toxicity.

released as soon as AlP or other phosphide salts get in contact with hydrochloric acid of the stomach (23).

In vitro studies (24-27) suggest that phosphides are absorbed as microscopic particles of unhydrolysed salt that permanently interact with free haemoglobin and haemoglobin in intact erythrocytes (rat and human) to produce a haemichrome (a methaemoglobin derivative resulting from distorted protein conformation). In addition, Potter et al. (26) report that Heinz bodies (denatured haemoglobin aggregates) are formed when phosphide concentration in vitro exceeds $1.25 \mu \mathrm{g} \mathrm{mL}^{-1}$.

Reports of in vivo phosphide poisoning showed intravascular complications such as haemolysis and methaemoglobinaemia, which support the involvement of erythrocytes in the biotransformation of phosphine in humans (24). Phosphine is excreted in the urine as hypophosphite and is also exhaled in the unchanged form (8).

\section{Organ toxicity}

The lethal dose of AlP is around $0.5 \mathrm{~g}$. Those who survived had either taken a very small amount, the tablet expired or phosphine gas evaporated because the tablet had been exposed to air. AlP poisoning affects most of the organs. Early symptoms include nausea, vomiting, retrosternal and epigastric pain, dyspnoea, anxiety, agitation, and garlic breath (28-30). The early signs of fatal toxicity ( $90 \%$ to $100 \%$ ) are shock and peripheral circulatory failure (31). Histopathological changes such as central venous congestion, degeneration of hepatocytes, and mononuclear infiltration are usually seen in the liver of poisoned patients. Furthermore, Mehrpour et al. (23) report alveolar thickening and dilated capillaries in the lung, degeneration of Nissl granule in the brain cytoplasm, degenerated eccentric nucleus in the cortex, and congestion within glomerulus and intraparenchymal part of the kidney.

\section{Gastrointestinal toxicity}

The early gastrointestinal symptoms of AlP ingestion include haematemesis, vomiting and epigastric pain. Endoscopy reveals corrosive lesions of the oesophagus and stomach, severe gastric erosions, duodenal erosions, and oesophageal strictures or fistula. Dysphagia is a common late complication (32-36). In our previous study, we described a family (a 35-year-old woman with her 18-year-old daughter and a 6-year-old son) who were accidentally poisoned with phosphine gas. They all 
had intensive abdominal pain, hyperglycaemia, hypotension, and severe thirst, and the boy died because of cardiopulmonary arrest before admission to the hospital (37).

A case of benign oesophagobronchial fistula secondary to AlP poisoning in a 17-year-old boy was reported recently. The patient presented with acute dysphagia and severe cough following every swallow of either a liquid or solid five to six days after AlP tablet ingestion (38).

In another report (39), dysphagia was observed in $38.87 \%$ of survivors after a mean interval of 38.6 days from the day of AlP poisoning. Oesophageal strictures were seen in $32.2 \%$ of the survivors. Two patients reported a tracheo-oesophageal fistula $20 \mathrm{~cm}$ to $22 \mathrm{~cm}$ from the incisors (39).

\section{Hepatic toxicity}

Jaundice as a clinical and laboratory indicator of liver damage is sometimes observed, but reports are controversial (31). Jaundice can even be a manifestation of another disturbances such as intravascular haemolysis (29). A more common finding is transient elevation of serum aspartate and alanine aminotransferase (40-43). The main histopathological findings in the liver at autopsy of fatal phosphine poisoning include cytoplasmic vacuolisation of hepatocytes and sinusoidal congestion. Nuclear fragmentation and sinusoidal clusters of polymorphonuclear leukocytes in the liver were also reported (44).

\section{Respiratory toxicity}

Tachypnoea, dyspnoea, crepitations and rhonchi are common signs of respiratory toxicity. Respiratory distress syndrome and other types of pulmonary oedema are common in adults, accompanied by protein-rich or haemorrhagic pleural effusions $(2,31$, 45-47).

\section{Cardiac toxicity}

Post-mortem reports of cardiac toxicity include heart failure (6), profound and refractory hypotension (42), heart congestion, subendocardial infarction or pericarditis, separation of myocardial fibres by oedema, fragmentation of the fibres, non-specific vacuolation of myocytes, focal necrosis, and neutrophil and eosinophil infiltration (41, 48, 49). Other signs and symptoms include, increased left ventricle, hypokinesia of the left ventricle and septum, akinesia, lower ejection fraction, severe hypotension, raised systemic venous pressure, normal pulmonary artery wedge pressure, inadequate systemic vasoconstriction, and electrocardiographic (ECG) abnormalities (2, 50-52) such as dysrhythmia, ST-T wave changes and conduction defects. Sinus tachycardia dominates in the first three to six hours of poisoning, followed by ST-T changes and conduction disturbances between hour 6 and twelve, and then by arrhythmias (49). Siwach et al. (53) found ventricular tachycardia in $40 \%$, ventricularfibrillation in $23.3 \%$, supraventricular tachycardia in $46.7 \%$, and atrial flutter/fibrillation in $20 \%$ of AlP-poisoned patients.

\section{Electrolyte and metabolic abnormalities}

Hypokalaemia (primary or secondary to vomiting), metabolic acidosis or mixed metabolic acidosis, respiratory alkalosis, and acute renal failure have often been reported (24). Hyperkalaemia, hypo- and hypernatraemia have also been observed in AlP poisoning, and these changes were associated with a higher mortality rate (54).

In experimental models, AlP may alter glucose homeostasis; it significantly decreases plasma glucose in AlP-treated rats (55) and horses (56). Hypoglycaemia has also been reported in other studies $(40,57-59)$. Some studies have reported a hyperglycaemic effect of AlP $(9,37,60)$ and some suggested that hyperglycaemia may be an important prognostic factor in AlP poisoning $(61,62)$, although not specific for AlP alone (20). In our earlier study, blood glucose was significantly higher in people who died of AlP poisoning than in those who survived (61). Controversial findings of blood sugar may reflect a wide variety of changes in magnesium, calcium, phosphate, citrate, and cortisol levels (60). Some studies reported increased blood magnesium in AlP poisoning $(31,52,63)$ and other reported hypomagnesaemia (64-67). Moreover, some studies $(68,69)$ found no change in blood magnesium. These differences between reports may also point to differences between analytical methods used.

Mehrpour et al. (23) have also reported that arrested oxidative phosphorylation and poor tissue perfusion may lead to lactic acidosis.

\section{Other effects}

Hepatitis, pancreatitis, acute adrenocortical insufficiency, acute tubular necrosis, and disseminated intravascular coagulation are less common findings 
in AlP poisoning (24). Refractory shock may result in cerebral anoxia that usually presents itself as drowsiness, delirium, and coma. Another uncommon sign is methaemoglobinaemia $(27,70)$.

There are interesting reports about spontaneous ignition and burns that occurred after oral poisoning with AlP (71-73). Phosphine gas is inflammable, depending on temperature and pressure. The absolute limit of flammability for phosphine in air is $1.8 \%$ $\left(17.9 \mathrm{mg} \mathrm{mm}^{-3}\right)$. When this limit is exceeded, phosphine can explode. Diphosphine, which is a product of the reaction between AlP and acid or moisture, burns spontaneously, reacting instantly with oxygen in the air, and this is one of the causes of explosions occurring during fumigation of storage grains (73). To prevent self-ignition AlP is mixed in the tablets with aluminium carbonate in the ratio $56: 44$, respectively (72).

\section{Sequelae in survivors?}

Only a few articles have described long-term disabilities due to AlP poisoning. Brautbar and Howard (74) described two patients, one with a longterm peripheral neuropathy, weakness and loss of sensation in the left-side extremities, severe headaches, fatigue, and dizziness and the other with the obstructive airway disease and headache (74). Kurzbauer and Kiesler (75) described a case of AlP poisoning with neurological abnormalities, such as Romberg, Rossolimo reflex on the left side, and bilateral Babinski. The neurological symptoms continued for 1.5 years post AlP exposure. Jain et al. (39) reported dysphagia, oesophageal strictures, and tracheoesophageal fistula in survivors a month after AlP exposure.

\section{Diagnosis of poisoning}

Although the diagnosis of AlP poisoning is often based on clinical suspicion or reports, a range of chemical and analytical tests are there to confirm it. One simple and sensitive spot test for the detection of phosphine gas in gastric fluid or breath is the silver nitrate test (76). Another test that can be performed on the gastric content is the ammonium molybdate test, which is both qualitative and quantitative (77). Gas chromatography is the most specific and sensitive method for detecting the presence of phosphine in blood/air and can detect even minute amounts of phosphine in the air (78).
Other salts of phosphide such as zinc phosphide $(\mathrm{ZnP})$ are also available in some countries that have the same mechanism of toxicity as AlP, but lower human mortality (79). Analytical tests help us to distinguish between AlP and $\mathrm{ZnP}$ poisoning and make a more accurate prognosis of the outcome. Hydrochloric acid is added to the sample (gastric contents or tissue), the mixture is heated, ammonium chloride and ammonium hydroxide added to the filtrate, and if the resulting gelatinous precipitate is white, it indicates the presence of $\mathrm{Al}(4)$.

\section{Management of poisoning}

Without a specific antidote, the management of AlP poisoning is very limited, mostly supportive. It is important do diagnose it as early as possible (see above). Before starting the treatment, medical staff should protect themselves with a full-face mask and rubber gloves. In cases of inhalation poisoning, the patient should be transferred to a well-ventilated space or fresh air. Contaminated clothes should be removed, and skin and eyes washed with tap water immediately. Gastric lavage with potassium permanganate, activated charcoal+sorbitol solution, and coconut oil can be performed in the first emergency step (80). Potassium permanganate (1:10 000 solution) oxidises phosphine gas in the stomach to phosphate, and reduces the amount of lethal phosphine gas $(9,80)$. Although charcoal is generally used for reducing phosphine absorption in the gastrointestinal system, no study has proved its efficacy in humans.

Bajwa et al. (81) recommended extensive gastric lavage with a mixture of sodium bicarbonate solution and coconut oil. The acidic environment of the stomach stimulates the conversion of AlP to phosphine gas, and lavage with sodium bicarbonate can be helpful.

Cardiac monitoring should include blood pressure and ECG to prevent arrhythmias and maintain tissue perfusion and oxygenation. One of the most common results of AlP toxicity is myocardial injury and haemodynamic instability (82).

Another necessary step in the management of AlP poisoning is early resuscitation with fluid and vasoactive agents to control central venous pressure (CVP) or pulmonary artery wedge pressure (PAWP). Norepinephrine or phenylephrine, dopamine, and dobutamine can be used to treat hypotension and refractory shock, while anti-arrhythmic agents, DC cardioversion, and temporary pacemaker should address the arrhythmia. Intra-aortic balloon pump 
(IABP) is a good way to mechanically support the heart, especially in toxic myocarditis with refractory shock (84). Trimetazidine has also proven itself effective recently in stopping ventricular ectopic beats and preserving oxidative metabolism (67). In addition, digoxin can be used to stabilise the left ventricular heart failure (82).

Early diagnosis of organ damage is another important aspect in the management, as AlP poisoning affects virtually all organs in the body. Acute lung injury may need endotracheal intubation and mechanical ventilation. Cyanosis not responding to oxygen therapy may be a sign of methaemoglobinaemia that requires therapy with intravenous methylene blue ( $1 \%$ solution) in the dose of $2 \mathrm{mg} \mathrm{kg}^{-1}$ of body weight over five minutes. For metabolic acidosis, intravenous sodium bicarbonate should be considered, whereas severe acidosis, volume overload or renal failure may require haemodialysis. However, haemodialysis is probably not very effective in removing phosphine (8). These new therapeutic approaches have been summarised in Table 1.

\section{Magnesium supplementation}

It is difficult to decide whether to give supplemental magnesium or not. Treatment with magnesium sulphate has been reported to reduce mortality by up to $50 \%(2,49,65,66)$. Magnesium stabilises the cell membrane and acts as an anti-oxidant. A study published in 1994 (69) compared treatments of AlPpoisoned patients and concluded that the survival rate of those who received supplemental magnesium was not significantly better than of those who did not (42 $\% v s .40 \%$, respectively). In contrast, in another case control study (65), magnesium improved survival of patients who ingested high doses of AlP. Moreover, a recent study (84) on a rat model showed that ${ }^{25} \mathrm{Mg}^{2+}$ carrying nanoparticle $\left({ }^{25} \mathrm{MgPMC} 16\right)$ significantly increased blood pressure and heart rate of rats poisoned with AlP. This study also demonstrated that ${ }^{25} \mathrm{MgPMC} 16$ increased intracardiac magnesium levels, reduced lipid peroxidation, and improved mitochondrial function.

\section{Hyperinsulinaemia-euglycaemia and hyperventilation oxygenation}

Some authors propose that a combination of hyperinsulinaemia-euglycaemia and hyperventilation oxygenation is worthy of more extensive evaluation as a therapy for AlP poisoning (85).

\section{$\mathrm{N}$-acetylcysteine}

Different studies in rats $(86,87)$ and humans $(66)$ have revealed that $\mathrm{N}$-acetylcysteine can help as it replenishes cellular glutathione and magnesium, in addition to its antioxidant properties. In rats exposed to AlP, $\mathrm{N}$-acetylcysteine increased survival time and reduced myocardial oxidative injury (4).

\section{Coconut and almond oil}

There are reports of the positive clinical effects of coconut oil against AlP poisoning in humans $(9,86)$. Its mechanism of action is unclear, but it may form a protective layer around the gastric mucosa and prevent the absorption of phosphine gas. In addition, coconut oil may dilute $\mathrm{HCl}$ in the stomach and reduce the breakdown of phosphide.

Saidi and Shoajaie (88) reported that intragastric lavage with sweet almond oil considerably reduced the mortality of rats poisoned with AlP. It also significantly lowered plasma cholinesterase levels. The authors suggested that sweet almond oil should be given orally immediately after AlP ingestion, but this has yet to be confirmed in humans.

\section{Hyperbaric oxygenation}

Saidi et al. (89) found that hyperbaric oxygenation improved the survival time in rats poisoned with AlP. However, its efficacy in humans has not been investigated.

\section{Digoxin}

It has been hypothesised that treatment with digoxin (rapid digitalisation) would increase myocardial contractility and blood pressure (90), countering thus the direct effects of AlP on cardiac myocytes which lead to refractory cardiogenic shock. Mehrpour et al. (82) have recently reported about successful treatment of an 18-year-old girl who had ingested a $3 \mathrm{~g}$ AlP tablet. On hospital admission her blood pressure was undetectable and she had a severe left ventricular systolic dysfunction. She received dopamine $\left(10 \mu \mathrm{g} \mathrm{kg}^{-1} \mathrm{~min}^{-1}\right)$ and digoxin $(0.5 \mathrm{mg})$ every six hours during the first day and continued with $0.25 \mathrm{mg}$ per day on the following days. The ECG parameters became normal on day three, and she was discharged on day 10 fully recovered.

\section{Hydroxyethyl starch}

Another option for the management of AlP poisoning is hydroxyethyl starch (91). Leakage of 
Table 1 New treatment strategies for AlP poisoning

\begin{tabular}{|c|c|c|c|c|c|}
\hline Study & Type of study & $\begin{array}{l}\text { New } \\
\text { Treatment }\end{array}$ & $\begin{array}{l}\text { Other } \\
\text { therapeutic } \\
\text { measures }\end{array}$ & Effects & Conclusion \\
\hline $\begin{array}{l}\text { Mehrpour } \\
\text { et al., } 2011 \\
(82)\end{array}$ & Case Report & $\begin{array}{l}\text { Digoxin } 0.5 \\
\text { mg initially } \\
\text { followed by } 0.5 \\
\text { mg at } 6 \mathrm{~h} \\
\text { intervals }\end{array}$ & $\begin{array}{l}\text { Gastric } \\
\text { decontamination } \\
\text { with } \mathrm{KMnO}_{4} \text {, } \\
\text { activated charcoal } \\
\text { and sodium } \\
\text { bicarbonate; } \\
\text { administration of } \\
\text { i.v. } \mathrm{Mg} \text { sulphate } \\
\text { and } \mathrm{Ca} \text { gluconate }\end{array}$ & $\begin{array}{l}\text { Resolved cardiogenic } \\
\text { shock due to left } \\
\text { ventricle failure }\end{array}$ & $\begin{array}{l}\text { Administration of } \\
\text { digoxin as an } \\
\text { adjustment therapy } \\
\text { can improve the out } \\
\text { come }\end{array}$ \\
\hline $\begin{array}{l}\text { Saidi et al., } \\
2011 \text { (89) }\end{array}$ & $\begin{array}{l}\text { Experimental } \\
\text { (Rats) }\end{array}$ & $\begin{array}{l}\text { Hyperbaric } \\
\text { oxygen }\end{array}$ & - & $\begin{array}{l}\text { Increasing survival } \\
\text { time }\end{array}$ & $\begin{array}{l}\text { Administration of } \\
\text { hyperbaric oxygen } \\
\text { may be also effective } \\
\text { in humans }\end{array}$ \\
\hline $\begin{array}{l}\text { Baeeri et } \\
\text { al., } 2011 \\
(84)\end{array}$ & $\begin{array}{l}\text { Experimental } \\
\text { (Rats) }\end{array}$ & $\begin{array}{l}{ }^{25} \mathrm{Mg}^{2+}- \\
\text { carrying } \\
\text { nanoparticle }\end{array}$ & $\begin{array}{l}\text { Na bicarbonate } \\
\left(4 \mathrm{mmol} \mathrm{kg}^{-1} \text {, }\right. \\
\text { i.v. })\end{array}$ & $\begin{array}{l}\text { Increased blood } \\
\text { pressure and heart } \\
\text { rate; increase in } \\
\text { antioxidant power, } \\
\text { Mg level in the } \\
\text { plasma and the heart; } \\
\text { reduction in lipid } \\
\text { peroxidation and } \\
\text { ADP/ATP ratio }\end{array}$ & $\begin{array}{l}{ }^{25} \mathrm{MgPMC} 16 \text { at } \\
0.025 \mathrm{LD}_{50}+\mathrm{Na} \\
\text { bicarbonate was the } \\
\text { most effective } \\
\text { combination }\end{array}$ \\
\hline $\begin{array}{l}\text { Saidi and } \\
\text { Shojaie., } \\
2011(88)\end{array}$ & $\begin{array}{l}\text { Experimental } \\
\text { (Rats) }\end{array}$ & $\begin{array}{l}\text { Intragastric } \\
\text { irrigation with } \\
\text { sweet almond } \\
\text { oil }\end{array}$ & - & $\begin{array}{l}\text { Protective role for } \\
\text { plasma cholinesterase } \\
\text { inhibition in AlP } \\
\text { poisoning, decreased } \\
\text { mortality rate }\end{array}$ & $\begin{array}{l}\text { Significant reduction } \\
\text { of mortality }\end{array}$ \\
\hline $\begin{array}{l}\text { Soltaninejad } \\
\text { et al., } 2011 \\
(95)\end{array}$ & Case Report & $\begin{array}{l}\text { Vitamin } C \\
(1 \mathrm{~g} \text { at } 6 \mathrm{~h} \\
\text { intervals, i.v. })+ \\
\text { methylene blue } \\
\left(1 \mathrm{mg} \mathrm{kg}^{-1} \text { of }\right. \\
1 \% \text { solution })\end{array}$ & $\begin{array}{l}\text { Supportive care, } \\
\text { Na bicarbonate, } \\
\text { norepinephrine, } \\
\text { Mg sulfate, } \mathrm{Ca} \\
\text { gluconate }\end{array}$ & $\begin{array}{l}\text { Twelve hours after } \\
\text { treatment with } \\
\text { vitamin C, the } \\
\text { methaemoglobin } \\
\text { concentration } \\
\text { decreased from } 46 \% \\
\text { to } 33 \% \text {. High doses } \\
\text { of methylene blue, } \\
\text { the methaemoglobin } \\
\text { concentration } \\
\text { decreased to } 23 \%\end{array}$ & $\begin{array}{l}\text { Administration of } \\
\text { vitamin } \mathrm{C} \text { followed } \\
\text { by methylene blue } \\
\text { may have a role in } \\
\text { successful treatment } \\
\text { of } \\
\text { methaemoglobinaemia } \\
\text { and haemolysis } \\
\text { following phosphine } \\
\text { poisoning }\end{array}$ \\
\hline $\begin{array}{l}\text { Bajwa et } \\
\text { al., } 2010 \\
(81)\end{array}$ & $\begin{array}{l}\text { Case Series } \\
\text { (33 patients) }\end{array}$ & $\begin{array}{l}\text { Extensive } \\
\text { gastric lavage } \\
\text { with aliquots of } \\
50 \mathrm{~mL} \text { of } \\
\text { coconut oil and } \\
50 \mathrm{~mL} \text { of } \\
\text { sodium } \\
\text { bicarbonate } \\
\text { solution with } \\
\text { simultaneous } \\
\text { aspiration }\end{array}$ & $\begin{array}{l}\text { Strict monitoring } \\
+ \text { Supportive } \\
\text { treatment }\end{array}$ & Survival rate $42 \%$ & $\begin{array}{l}\text { Recommendation to } \\
\text { intensivists and } \\
\text { physicians to use this } \\
\text { particular regimen of } \\
\text { gastric } \\
\text { decontamination }\end{array}$ \\
\hline
\end{tabular}


Table 1 Continuation

\begin{tabular}{|c|c|c|c|c|c|}
\hline Study & Type of study & $\begin{array}{l}\text { New } \\
\text { Treatment }\end{array}$ & $\begin{array}{l}\text { Other } \\
\text { therapeutic } \\
\text { measures }\end{array}$ & Effects & Conclusion \\
\hline $\begin{array}{l}\text { Siddaiah et } \\
\text { al., } 2009 \\
(83)\end{array}$ & Case Report & $I A B P^{*}$ & $\begin{array}{l}\text { Supportive care, } \\
\text { inotropes and } \\
\text { mechanical } \\
\text { ventilation }\end{array}$ & $\begin{array}{l}\text { IABP was used for } \\
\text { cardiovascular } \\
\text { support until the } \\
\text { effects of AlP } \\
\text { resolved }\end{array}$ & $\begin{array}{l}\text { IABP used for } \\
\text { treatment of } \\
\text { cardiogenic shock due } \\
\text { to AlP poisoning can } \\
\text { improve the outcome }\end{array}$ \\
\hline $\begin{array}{l}\text { Azad et al., } \\
2011 \text { (96) }\end{array}$ & $\begin{array}{l}\text { Experimental } \\
\text { (Rats) }\end{array}$ & $\begin{array}{l}N A C^{* *} \\
\left(6.25 \mathrm{mg} \mathrm{kg}{ }^{-1}\right. \\
\min ^{-1}, i . v . \text { for } \\
30 \mathrm{~min})\end{array}$ & & $\begin{array}{l}\text { Significantly } \\
\text { increased survival } \\
\text { time, stabilization of } \\
\text { blood pressure and } \\
\text { heart rate, decreased } \\
\text { MDA }^{* * *} \text { level and } \\
\text { increased GSH Px } \\
\text { levels }\end{array}$ & $\begin{array}{l}\text { NAC increased the } \\
\text { survival time by } \\
\text { reducing myocardial } \\
\text { oxidative injury }\end{array}$ \\
\hline $\begin{array}{l}\text { Azad et al., } \\
2011 \text { (96) }\end{array}$ & $\begin{array}{l}\text { Experimental } \\
\text { (Rats) }\end{array}$ & $\begin{array}{l}\boldsymbol{L}-\boldsymbol{N} \boldsymbol{A M \boldsymbol { E } ^ { * * * * * * }} \text { : } \\
\left(1 \mathrm{mg} \mathrm{kg}{ }^{-1}\right. \\
\min ^{-1}, i . v . \text { for } \\
60 \mathrm{~min})\end{array}$ & & $\begin{array}{l}\text { Significant rise in } \\
\text { blood pressure but } \\
\text { precipitated ECG } \\
\text { abnormalities. Pre- } \\
\text { and post-treatment of } \\
\text { L-NAME with AlP } \\
\text { neither improved the } \\
\text { survival time nor the } \\
\text { biochemical } \\
\text { parameters despite } \\
\text { significant rise in } \\
\text { blood pressure }\end{array}$ & $\begin{array}{l}\text { L-NAME showed no } \\
\text { protective effects in } \\
\text { rats exposed to AlP }\end{array}$ \\
\hline $\begin{array}{l}\text { Mittra et al., } \\
2001 \text { (97) }\end{array}$ & $\begin{array}{l}\text { Experimental } \\
\text { (Rats) }\end{array}$ & $\begin{array}{l}\text { Atropine } \\
\left(1 \mathrm{mg} \mathrm{kg}^{-1},\right. \\
\text { intra } \\
\text { peritoneal })+ \\
\text { pralidoxime } \\
\left(5 \mathrm{mg} \mathrm{kg}^{-1},\right. \\
\text { intra } \\
\text { peritoneal }) \\
\text { administered } \\
\text { five minutes } \\
\text { after AlP } \\
\text { exposure }\end{array}$ & - & $\begin{array}{l}\text { Increased survival } \\
\text { time. Plasma } \\
\text { cholinesterase levels } \\
\text { were inhibited in rats } \\
\text { poisoned with AlP as } \\
\text { compared to controls }\end{array}$ & $\begin{array}{l}\text { Atropine and } \\
\text { pralidoxime can } \\
\text { increase survival time }\end{array}$ \\
\hline $\begin{array}{l}\text { Dueñas et } \\
\text { al., } 1999 \\
(67)\end{array}$ & Case Report & $\begin{array}{l}\text { Oral dose of } \\
20 \mathrm{mg} \\
\text { trimetazidine } \\
\text { twice daily }\end{array}$ & $\begin{array}{l}\text { Mg sulphate } \\
\text { intravenously at } 3 \\
\text { g over } 30 \mathrm{~min}\end{array}$ & $\begin{array}{l}\text { Resolved } \\
\text { dysrhythmia due to } \\
\text { AlP poisoning after } \\
48 \mathrm{~h} \text { [ventricular } \\
\text { premature complexes } \\
\left(>600 \mathrm{~h}^{-1}\right) \text { with } \\
\text { periods of bigeminy] }\end{array}$ & $\begin{array}{l}\text { Ventricular } \\
\text { dysrhythmias were } \\
\text { treated solely with } \\
\text { oral trimetazidine } \\
\text { tresulting in rapid } \\
\text { disappearance of all } \\
\text { electrocardiographic } \\
\text { abnormalities }\end{array}$ \\
\hline
\end{tabular}

*IABP: Intra-aortic Balloon Pump

**NAC: $N$-Acetylcysteine

***MDA: Malonyldialdehyde

****GSH Px: Glutathione peroxidase

*****L-NAME: $N$-omega-nitro-L-arginine methyl ester 
fluids from intravascular to extravascular space that leads to a strong refractory hypotension is one of the post-mortem findings in AlP poisoning. Hydroxyethyl starch remains in the intravascular space as a colloid rather than as a crystalloid and thus reduces the extravascular leak of albumin and fluids (91). However, no experiment has yet investigated the use of starch in the management of AlP poisoning.

\section{Prognosis of AlP poisoning}

The mortality in adults who have ingested $500 \mathrm{mg}$ of AlP or over is between $30 \%$ and $100 \%$. The higher the blood phosphine, the higher the mortality. Patients having blood phosphine levels equal to or less than $1.067 \pm 0.16 \mathrm{mg}$ survived, and this dose seems to be the lethal threshold of phosphine toxicity (92). Survival may increase if a very small amount of AlP is ingested or the tablet has expired or was exposed to air (12). Vomiting and early supportive care also increase the survival rate (8).

Poor prognosis is indicated by hyperglycaemia, high simplified acute physiology score (SAPS II), hypotension, acidosis, leukocytosis, hyperuraemia, ECG abnormalities, high acute physiology and chronic health evaluation score (APACHE II), low Glasgow coma scale, acute renal failure, low prothrombin rate, hyperleukocytosis, methaemoglobinaemia, use of vasoactive drugs, lack of vomiting after ingestion, and use of mechanical ventilation $(4,61,70,93,94)$.

To conclude, acute AlP poisoning is a worldwide problem. The understanding of its mechanisms of toxicity and clinical effects has improved in the recent years. An antidote proper for phosphine poisoning is still unavailable. A number of possibilities for treatment have been tried out or experimented with, but they all need further validation (see Table 1). Meanwhile, preventive measures might help to control the risk of poisoning in humans such as limited access to phosphide compounds, regulations to ban its use as a pesticide, and keeping health professionals abreast with the latest knowledge about early management of phosphide poisoning.

\section{Acknowledgment}

This review has been written upon an invitation to Professor Mohammad Abdollahi by the Archives of Industrial Hygiene and Toxicology. The paper is the outcome of an in-house, financially unsupported study.

\section{REFERENCES}

1. Singh D, Dewan I, Pandey AN, Tyagi S. Spectrum of unnatural fatalities in the Chandigarh zone of north-west India: a 25 year autopsy study from a tertiary care hospital. J Clin Forensic Med 2003;10:145-52.

2. Gupta S, Ahlawat SK. Aluminum phosphide poisoning: a review. J Toxicol Clin Toxicol 1995;33:19-24.

3. Shadnia S, Sasanian G, Allami P, Hosseini A, Ranjbar A, Amini-Shirazi N, Abdollahi M, 2009. A retrospective 7-years study of aluminum phosphide poisoning in Tehran: opportunities for prevention. Hum Exp Toxicol 2009;28:20913.

4. Bogle RG, Theron P, Brooks P, Dargan PI, Redhead J. Aluminium phosphide poisoning. Emerg Med J 2006;23: e03.

5. Andersen TS, Holm JW, Andersen TS. Forgiftning med muldvarpegasningsmidlet aluminiumfosfid [Poisoning with aluminum phospholipide used as a poison against moles, in Danish]. Ugeskr Laeger 1996;158:5308-9.

6. Alter P, Grimm W, Maisch B. Lethal heart failure caused by aluminium phosphide poisoning. Intensive Care Med 2001;27:327.

7. Anger F, Paysant F, Brousse F, Le Normand I, Develay P, Gaillard Y, Baert A, Le Gueut MA, Pepin G, Anger JP. Fatal aluminum phosphide poisoning. J Anal Toxicol 2000;24:902.

8. Gurjar M, Baronia AK, Azim A, Sharma K. Managing aluminum phosphide poisonings. J Emerg Trauma Shock 2011;4:378-84.

9. Shadnia S, Rahimi M, Pajoumand A, Rasouli MH, Abdollahi M. Successful treatment of acute aluminium phosphide poisoning: possible benefit of coconut oil. Hum Exp Toxicol 2005;24:215-8.

10. Eddleston M, Phillips MR. Self poisoning with pesticides. Br Med J 2004;328:42-4.

11. Jeyaratnam J. Acute pesticide poisoning: a major global health problem. World Health Stat Q 1990;43:139-44.

12. Mehrpour O, Singh S. Rice tablet poisoning: a major concern in Iranian population. Hum Exp Toxicol 2010;29:701-2.

13. Lauterbach M, Solak E, Kaes J, Wiechelt J, Von Mach MA, Weilemann LS. Epidemiology of hydrogen phosphide exposures in humans reported to the poison center in Mainz, Germany, 1983-2003. Clin Toxicol (Phila) 2005;43:57581.

14. Price NR, Moles KA, Humphires OA. Phosphine toxicity and catalase activity in susceptible and resistant strains of lesser grain borer (Rhyzopertha dominica). Comp Biochem Physiol 1982;73:411-5.

15. Bolter CJ, Chefurka W. Extramitochondrial release of hydrogen peroxide from insect and mouse liver mitochondria using the respiratory inhibitors phosphine, myxothiazol, and antimycin and spectral analysis of inhibited cytochromes. Arch Biochem Biophys 1990;278:65-72.

16. Chugh SN, Arora V, Sharma A, Chugh K. Free radical scavengers and lipid peroxidation in acute aluminium phosphide poisoning. Indian J Med Res 1996;104:190-3.

17. Dua R, Gill KD. Aluminium phosphide exposure: implications on rat brain lipid peroxidation and antioxidant defence system. Pharmacol Toxicol 2001;89:315-9. 
18. Abdollahi M, Ranjbar A, Shadnia S, Nikfar S, Rezaie A. Pesticides and oxidative stress: a review. Med Sci Monit 2004;10:RA141-7.

19. Nath NS, Bhattacharya I, Tuck AG, Schlipalius DI, Ebert PR. Mechanisms of phosphine toxicity. J Toxicol 2011;2011:494168. Epub 2011 Apr 28.

20. Rahimi R, Abdollahi M. A review on the mechanisms involved in hyperglycemia induced by organophosphorus pesticides. Pestic Biochem Physiol 2007;88:115-21.

21. Al-Azzawi MJ, Al-Hakkak ZS, Al-Adhami BW. In vitro inhibitory effects of phosphine on human and mouse serum cholinesterase. Toxicol Environ Chem 1990;29:53-6.

22. Wilson R, Lovejoy FH, Jaeger RJ, Landrigan PL. Acute phosphine poisoning aboard a grain freighter. Epidemiologic, clinical, and pathological findings. JAMA 1980;244:14850 .

23. Mehrpour O, Dolati M, Soltannejad K, Shadnia S, Nazparvar B. Evaluation of histopathological changes in fatal aluminum phosphide poisoning. Indian J Forensic Med Toxicol 2008;2:34-6.

24. Proudfoot AT. Aluminium and zinc phosphide poisoning. Clin Toxicol (Phila) 2009;47:89-100.

25. Chin KL, Mai X, Meaklim J, Scollary GR, Leaver DD. The interaction of phosphine with haemoglobin and erythrocytes. Xenobiotica 1992;22:599-607.

26. Potter WT, Rong S, Griffith J, White J, Garry VF. Phosphinemediated Heinz body formation and hemoglobin oxidation in human erythrocytes. Toxicol Lett 1991;57:37-45.

27. Shadnia S, Soltaninejad K, Hassanian-Moghadam H, Sadeghi A, Rahimzadeh H, Zamani N, Ghasemi-Toussi A, Abdollahi M. Methemoglobinemia in aluminum phosphide poisoning. Hum Exp Toxicol 2011;30:250-3.

28. Popp W, Mentfewitz J, Götz R, Voshaar T. Phosphine poisoning in a German office. Lancet 2002;359:1574.

29. Aggarwal P, Handa R, Wig N, Biswas A, Saxena R, Wali JP. Intravascular hemolysis in aluminium phosphide poisoning. Am J Emerg Med 1999;17:488-9.

30. Sood AK, Mahajan A, Dua A. Intravascular haemolysis after aluminium phosphide ingestion. J R Soc Med 1997;90:478.

31. Singh RB, Singh RG, Singh U. Hypermagnesemia following aluminum phosphide poisoning. Int J Clin Pharmacol Ther Toxicol 1991;29:82-5.

32. Chugh SN, Dushyant, Ram S, Arora B, Malhotra KC. Incidence and outcome of aluminium phosphide poisoning in a hospital study. Indian J Med Res 1991;94:232-5.

33. Chhina RS, Thukral R, Chawla LS. Aluminum phosphideinduced gastroduodenitis. Gastrointest Endosc 1992;38:6356.

34. Nijhawan S, Rastogi M, Tandon M, Mathur A, Rai RR. Aluminum phosphide-induced esophageal stricture: an unusual complication. Endoscopy 2006;38(Suppl 2):E23.

35. Talukdar R, Singal DK, Tandon RK. Aluminium phosphideinduced esophageal stricture. Indian J Gastroenterol 2006;25:98-9.

36. Madan K, Chalamalasetty SB, Sharma M, Makharia G. Corrosive-like strictures caused by ingestion of aluminium phosphide. Natl Med J India 2006;19:313-4.

37. Shadnia S, Mehrpour O, Abdollahi M. Unintentional poisoning by phosphine released from aluminum phosphide. Hum Exp Toxicol 2008;27:87-9.
38. Bhargava S, Rastogi R, Agarwal A, Jindal G. Esophagobronchial fistula - A rare complication of aluminum phosphide poisoning. Ann Thorac Med 2011;6:41-2.

39. Jain RK, Gouda NB, Sharma VK, Dubey TN, Shende A, Malik R, Tiwari G. Esophageal complications following aluminium phosphide ingestion: an emerging issue among survivors of poisoning. Dysphagia 2011;25:271-6.

40. Frangides CY, Pneumatikos IA. Persistent severe hypoglycemia in acute zinc phosphide poisoning. Intensive Care Med 2002;28:223.

41. Akkaoui M, Achour S, Abidi K, Himdi B, Madani A, Zeggwagh AA, Abouqal R. Reversible myocardial injury associated with aluminum phosphide poisoning. Clin Toxicol (Phila) 2007;45:728-31.

42. Bayazit AK, Noyan A, Anarat A. A child with hepatic and renal failure caused by aluminum phosphide. Nephron 2000;86:517.

43. Memiş D, Tokatlioglu D, Koyuncu O, Hekimoglu S. Fatal aluminium phosphide poisoning. Eur J Anaesthesiol 2007;24:292-3.

44. Saleki S, Ardalan FA, Javidan-Nejad A. Liver histopathology of fatal phosphine poisoning. Forensic Sci Int 2007;166:1903.

45. Chugh SN, Ram S, Mehta LK, Arora BB, Malhotra KC. Adult respiratory distress syndrome following aluminium phosphide ingestion. Report of 4 cases. J Assoc Physicians India 1989;37:271-2.

46. Chugh SN, Aggarwal HK, Mahajan SK. Zinc phosphide intoxication symptoms: analysis of 20 cases. Int J Clin Pharmacol Ther 1998;36:406-7.

47. Singh S, Singh D, Wig N, Jit I, Sharma BK. Aluminum phosphide ingestion: a clinico-pathologic study. J Toxicol Clin Toxicol 1996;34:703-6.

48. Chugh SN, Chugh K, Ram S, Malhotra KC. Electrocardiographic abnormalities in aluminium phosphide poisoning with special reference to its incidence, pathogenesis, mortality and histopathology. J Indian Med Assoc 1991;89:325.

49. Katira R, Elhence GP, Mehrotra ML, Srivastava SS, Mitra A, Agarwala R, Ram A. A study of aluminum phosphide (AlP) poisoning with special reference to electrocardiographic changes. J Assoc Physicians India 1990;38:471-3.

50. Bhasin P, Mittal HS, Mitra A. An echocardiographic study in aluminium phosphide poisoning. J Assoc Physicians India 1991;39:851.

51. Kalra GS, Anand IS, Jit I, Bushnurmath B, Wahi PL. Aluminium phosphide poisoning: haemodynamic observations. Indian Heart J 1991;43:175-8.

52. Singh RB, Rastogi SS, Singh DS. Cardiovascular manifestations of aluminium phosphide intoxication. J Assoc Physicians India 1989;37:590-2.

53. Siwach SB, Singh H, Jagdish, Katyal VK, Bhardwaj G. Cardiac arrhythmias in aluminium phosphide poisoning studied by on continuous holter and cardioscopic monitoring. J Assoc Physicians India 1998;46:598-601.

54. Mehrpour O, Shadnia S, Soltannejad K, Yaghmaei A. Evaluation of electrolytes and blood glucose level in aluminum phosphide poisoning. Scientific J Forensic Med 2009;15:49-53.

55. Dua R, Kumar V, Sunkaria A, Gill KD. Altered glucose homeostasis in response to aluminium phosphide induced 
cellular oxygen deficit in rat. Indian J Exp Biol 2010;48:722 30 .

56. Easterwood L, Chaffin MK, Marsh PS, Porter B, Barr C. Phosphine intoxication following oral exposure of horses to aluminum phosphide-treated feed. J Am Vet Med Assoc 2010;236:446-50.

57. Chugh SN, Kishore K, Aggarwal N, Attri S. Aluminium phosphide (ALP) is a widely used fumigant posticide. J Assoc Physicians India 2000;48:855-6.

58. Singh B, Gupta S, Minocha SK,Aggarwal NM. Hypoglycaemia in aluminium phosphide poisoning. J Assoc Physicians India 1994:42:663.

59. Patial RK, Bansal SK, Kashyap S, Sharma AK, Sharma B Hypoglycaemia following zinc phosphide poisoning. JAssoc Physicians India 1990;38:306-7.

60. Abder-Rahman H. Effect of aluminum phosphide on blood glucose level. Vet Hum Toxicol 1999;41:31-2.

61. Mehrpour O, Alfred S, Shadnia S, Keyler DE, Soltaninejad $\mathrm{K}$, Chalaki N, Sedaghat M. Hyperglycemia in acute aluminum phosphide poisoning as a potential prognostic factor. Hum Exp Toxicol 2008;27:591-5.

62. Mehrpour O, Keyler D, Shadnia S. Comment on aluminum and zinc phosphide poisoning. Clin Toxicol (Phila) 2009;47:838-9

63. Singh RB, Saharia RB, Sharma VK. Can aluminium phosphide poisoning cause hypermagnesaemia? A study of 121 patients. Magnes Trace Elem 1990;9:212-8.

64. Chugh SN, Jaggal KL, Sharma A, Arora B, Malhotra KC. Magnesium levels in acute cardiotoxicity due to aluminium phosphide poisoning. Indian J Med Res 1991;94:437-9.

65. Chugh SN, Kamar P, Sharma A, Chugh K, Mittal A, Arora B. Magnesium status and parenteral magnesium sulphate therapy in acute aluminum phosphide intoxication. Magnes Res 1994;7:289-94.

66. Chugh SN, Kolley T, Kakkar R, Chugh K, Sharma A. A critical evaluation of anti-peroxidant effect of intravenous magnesium in acute aluminium phosphide poisoning. Magnes Res 1997;10:225-30.

67. Dueñas A, Pérez-Castrillon JL, Cobos MA, Herreros V. Treatment of the cardiovascular manifestations of phosphine poisoning with trimetazidine, a new antiischemic drug. Am J Emerg Med 1999;17:219-20.

68. Siwach SB, Singh P, Ahlawat S, Dua A, Sharma D. Serum and tissue magnesium content in patients of aluminium phosphide poisoning and critical evaluation of high dose magnesium sulphate therapy in reducing mortality. J Assoc Physicians India 1994;42:107-10.

69. Siwach SB, Singh P, Ahlawat S. Magnesium in aluminium phosphide poisoning - where have we erred? J Assoc Physicians India 1994;42:193-4.

70. Mostafazadeh B, Pajoumand A, Farzaneh E, Aghabiklooei A, Rasouli MR. Blood levels of methemoglobin in patients with aluminum phosphide poisoning and its correlation with patient's outcome. J Med Toxicol 2011;7:40-3.

71. Shadnia S, Soltaninejad K. Spontaneous ignition due to intentional acute aluminum phosphide poisoning. J Emerg Med 2011;40:179-81.

72. Wahab A, Rabbani MU, Wahab S, Khan RA. Spontaneous self-ignition in a case of acute aluminium phosphide poisoning. Am J Emerg Med 2009;27:752.e5-6.
73. Yadav J, Athawal BK, Dubey BP, Yadav VK. Spontaneous ignition in case of celphos poisoning. Am J Forensic Med Pathol 2007;28:353-5.

74. Brautbar N, Howard J. Phosphine toxicity: report of two cases and review of the literature. Toxicol Ind Health 2002;18:71-5.

75. Kurzbauer $\mathrm{H}$, Kiesler A. Zawodowe zatrucie fosforowodorem [Occupational phosphine poisoning, in Polish]. Neurol Neurochir Pol 1987;21:415-7.

76. Chugh SN, Ram S, Chugh K, Malhotra KC. Spot diagnosis of aluminium phosphide ingestion: an application of a simple test. J Assoc Physicians India 1989;37:219-20.

77. Bumbrah GS, Krishan K, Kanchan T, Sharma M, Sodhi GS. Phosphide poisoning: A review of literature. Forensic Sci Int 2012;214:1-6.

78. Anand R, Binukumar BK, Gill KD. Aluminum phosphide poisoning: an unsolved riddle. J Appl Toxicol 2011;31:499505.

79. Siwach SB, Gupta A. The profile of acute poisonings in Harayana-Rohtak Study. J Assoc Physicians India 1995;43:756-9.

80. Pajoumand A, Jalali N, Abdollahi M, Shadnia S. Survival following severe aluminum phosphide poisoning. J Pharm Pract Res 2002;32:297-9.

81. Bajwa SJ, Bajwa Kaur SK, Kaur J, Singh K, Panda A. Management of celphos poisoning with a novel intervention: A ray of hope in the darkest of clouds. Anesth Essays Res 2010;4:20-4.

82. Mehrpour O, Farzaneh E, Abdollahi M. Successful Treatment of aluminum phosphide poisoning with digoxin: a case report and review of literature. Int J Pharmacol 2011;7:761-4.

83. Siddaiah L, Adhyapak S, Jaydev S, Shetty G, Varghese K, Patil C, Iyengar S. Intra-aortic balloon pump in toxic myocarditis due to aluminum phosphide poisoning. J Med Toxicol 2009;5:80-3.

84. Baeeri M, Shariatpanahi M, Baghaei A, Ghasemi-Niri SF, Mohammadi H, Mohammadirad A, Hassani S, Bayrami Z, Hosseini A, Rezayat SM, Abdollahi M. On the benefit of magnetic magnetic magnesium nanocarrier in cardiovascular toxicity of aluminum phosphide. Toxicol Ind Health 2011. [Epub ahead of print]

85. Hassanian-Moghaddam H, Pajoumand A. Two years epidemiological survey of aluminium phosphide poison. Iranian J Toxicol 2007;1:1-9.

86. Hsu C, Han B, Liu M, Yeh C, Casida JE. Phosphine-induced oxidative damage in rats: attenuation by melatonin. Free Radic Biol Med 2000;28:636-42.

87. Hsu CH, Chi BC, Liu MY, Li JH, Chen CJ, Chen RY. Phosphine-induced oxidative damage in rats: role of glutathione. Toxicology 2002;179:1-8.

88. Saidi H, Shojaie S. Effect of sweet almond oil on survival rate and plasma cholinesterase activity of aluminum phosphide-intoxicated rats. Hum Exp Toxicol 2011. [Epub ahead of print]

89. Saidi H, Shokraneh F, Ghafouri HB, Shojaie SJ. Effects of hyperbaric oxygenation on survival time of aluminum phosphide intoxicated rats. J Res Med Sci 2011;16:130612.

90. Sanaei-Zadeh H, Farajidana H. Is there a role for digoxin in the management of acute aluminum phosphide poisoning? Med Hypotheses 2011;76:765-6. 
91. Marashi SM, Arefi M, Behnoush B, Nasrabad MG, Nasrabadi $\mathrm{ZN}$. Could hydroxyethyl starch be a therapeutic option in management of acute aluminum phosphide toxicity? Med Hypotheses 2011;76:596-8.

92. Chugh SN, Pal R, Singh V, Seth S. Serial blood phosphine levels in acute aluminium phosphide poisoning. J Assoc Physicians India 1996;44:184-5.

93. Shadnia S, Mehrpour O, Soltaninejad K. A simplified acute physiology score in the prediction of acute aluminum phosphide poisoning outcome. Indian J Med Sci 2010;64:532 9.

94. Louriz M, Dendane T, Abidi K, Madani N, Abouqal R, Zeggwagh AA. Prognostic factors of acute aluminum phosphide poisoning. Indian J Med Sci 2009;63:227-34.
95. Soltaninejad K, Nelson LS, Khodakarim N, Dadvar Z, Shadnia S. Unusual complication of aluminum phosphide poisoning: Development of hemolysis and methemoglobinemia and its successful treatment. Indian J Crit Care Med 2011;15:117-9.

96. Azad A, Lall SB, Mittra S. Effect of N-acetylcysteine and L-NAME on aluminium phosphide induced cardiovascular toxicity in rats. Acta Pharmacol Sin 2001;22:298-304.

97. Mittra S, Peshin SS, Lall SB. Cholinesterase inhibition by aluminium phosphide poisoning in rats and effects of atropine and pralidoxime chloride. Acta Pharmacol Sin 2001;22:379. 


\section{Sažetak}

\section{SUSTAVNI PREGLED OTROVANJA ALUMINIJEVIM FOSFIDOM}

Svake godine u svijetu oko 300.000 ljudi umre od trovanja pesticidima. Najčešći pesticidni spojevi su organofosfati i fosfidi, ponajviše aluminijev fosfid. On je poznat kao otrov samoubojica, jer ga je lako nabaviti, a nema djelotvornoga protuotrova. Toksičnost duguje otpuštanju fosfinskoga plina u trenutku kada tableta dođe u dodir s vlažnim okružjem. Fosfinski plin ponajviše djeluje na srce, pluća, probavni sustav i bubrege. Znakovi i simptomi trovanja obuhvaćaju mučninu, povraćanje, uznemirenost, bol u trbuhu, lupanje srca, refraktorni šok, srčane aritmije, plućni edem, dispneju, cijanozu i osjetilne promjene. Dijagnoza se zasniva na kliničkom opažanju, pozitivnom nalazu testa na fosfin sa srebrnim nitratom, aspiratu iz želuca te biokemiji crijeva. Otkrije li se rano, liječenje obuhvaća ispiranje želuca kalijevim permanganatom, odnosno kombinacijom kokosova ulja i natrijeva bikarbonata, aktivni ugljen te palijativnu skrb. Usmjereno liječenje obuvhaća intravensku primjenu magnezijeva sulfata i kokosova ulja. Korisnim se može pokazati liječenje acidoze ranom intravenskom primjenom natrijeva bikarbonata i liječenje srčanoga šoka odgovarajućom tekućinom i vazopresorom te refraktornog šoka, intraaortalnim balonom odnosno digoksinom.

Korisnim se može pokazati i trimetazidin, budući da sprječava ventrikularne ekstrasistole i bigeminiju te čuva oksidativni metabolizam. Ovaj članak donosi pregled različitih vidova trovanja aluminijevim fosfidom, uključujući njegovu epidemiologiju, toksičnost, kliničke znakove i simptome te medicinsku obradu.

KLJUČNE RIJEČI: fosfin, pesticidi, toksičnost, trovanje

\section{CORRESPONDING AUTHOR:}

Mohammad Abdollahi

Faculty of Pharmacy, and Pharmaceutical Sciences

Research Center

Tehran University of Medical Sciences (TUMS),

Tehran 1417614411, Iran

E-mail: Mohammad.abdollahi@utoronto.ca 